\title{
Morphometric Analysis of Burhner River Watershed Using Remote Sensing and GIS Technique
}

\author{
J Himanshu Rao ${ }^{1 *}$, S.K. Sharma ${ }^{1}$, M.K. Awasthi ${ }^{1}$, S.K. Pyasi ${ }^{1}$ and S.K. Pandey ${ }^{2}$ \\ ${ }^{1}$ Department of Soil and Water Engineering, College of Agricultural Engineering, JNKVV, Jabalpur, Madhya Pradesh, India \\ ${ }^{2}$ Department of Horticulture, College of Agriculture, JNKVV, Jabalpur, Madhya Pradesh, India
}

"Corresponding author: j.himanshurao@gmail.com (ORCID ID: 0000-0003-2553-7069)

Paper No. 947

Received: 26-08-2021

Revised: $23-11-2021$

Accepted: 13-12-2021

\begin{abstract}
Proper knowledge of hydrological response of a watershed is of utmost importance in order to implement watershed development works in the watersheds. Morphometric analysis of a watershed thus helps in understanding the hydrological response of watersheds in hydrological data-scarce conditions. The present study attempts to perform the morphometric analysis of sub-watersheds inherent in Burhner river watershed situated in Mandla, Balaghat and Dindori districts of Madhya Pradesh, India. A total of 17 subwatersheds were delineated in the study area using CARTOSAT DEM (Digital Elevation Model), having a spatial resolution of $30 \mathrm{~m}$. Stream network of the study area was obtained using DEM in ArcGIS 9.3®. The findings of the study revealed that out of $17 \mathrm{sub}$-watersheds, three sub-watersheds were of $8^{\text {th }}$ order, eight sub-watersheds were of $7^{\text {th }}$ order and six sub-watersheds were of $6^{\text {th }}$ order. The drainage pattern of the study area was found as dendritic to sub-dendritic, approaching like the branching of a tree. Linear, areal, shape and relief morphometric parameters were calculated using the standard formulas. High values of a linear morphometric parameter such as mean bifurcation ratio revealed geomorphological control over the entire watershed. In addition, higher values of areal morphometric parameters such as drainage density, stream frequency, texture ratio with lower values of length of overland flow and constant of channel maintenance suggested channel flow as dominating in the sub-watersheds with a higher risk of soil erosion in the sub-watersheds. Analysis of shape morphometric parameters (i.e. form factor, circularity ratio, elongation ratio, compactness coefficient and shape factor) and relief morphometric parameters (i.e. relief ratio, relative relief and ruggedness number) also revealed that sub-watersheds are more prone to soil erosion. The study aided in understanding the hydrological behaviour of subwatersheds of Burhner river watershed which can be further considered for sustainable management of natural resources in sub-watersheds.
\end{abstract}

\section{HIGHLIGHTS}

(0 The study was conducted in Burhner river watershed situated in Mandla, Balaghat and Dindori districts of Madhya Pradesh, India, to determine morphometric parameters of inherent sub-watersheds.

( Hydrological response of 17 sub-watersheds of Burhner river watershed was studied, indicating that sub-watersheds are more prone to soil erosion.

Keywords: Morphometric analysis, drainage basin characteristics, remote sensing, geographic information system

A watershed is a natural hydrological unit that generates surface runoff from the rainfall, which flows through channels, streams, river, lakes or oceans (Gajbhiye et al. 2015a; Meshram et al. 2017). Mismanagement of natural resources (i.e. land and water) for the fulfilment of human needs has substantially caused watershed deterioration at a rapid pace in recent times (Sharma et al. 2008; Gajbhiye and Sharma 2016; Sharma et al. 2016).

How to cite this article: Rao, J.H., Sharma, S.K., Awasthi, M.K., Pyasi, S.K. and Pandey, S.K. 2021. Morphometric Analysis of Burhner River Watershed Using Remote Sensing and GIS Technique. Int. J. Ag. Env. Biotech., 14(04): 585-599.

Source of Support: None; Conflict of Interest: None 
Watershed deterioration is one of the common issues in India and it also influences at global scale (Prabhakar et al. 2019).

Watershed is a geographical unit with a natural boundary where it is a logical choice to practice morphometric analysis in order to understand its hydrological response (Ahmed et al. 2018). Morphometric analysis is the science of measurement and mathematical estimation of the earth's shape, size and dimension of its landform (Clarke, 1966; Agarwal, 1998; Sharma et al. 2012).

Basin or watershed morphometry, among other aspects of morphometric analysis, is of great importance to hydrologists, geomorphologists to address serious environmental issues like soil erosion, slope instability, flood, landslides and extreme surface runoff (Sharma et al. 2011; Sharma et al. 2014; Mangan, 2019). Other basin characteristics such as travel time, time to peak and intensity of erosional processes can be predicted with better insights and accuracy through morphometric analysis (Altaf et al. 2013; Patil et al. 2017). Furthermore, it could be a good alternative in ungauged watersheds where information on hydrology are scarce (Romshoo et al. 2012; Gajbhiye et al. 2015b; Meshram and Sharma, 2017; Puno and Puno, 2019). A well-planned watershed management practice can mitigate the effect of prominent watershed deterioration, causing factors such as excessive runoff, low productive yield, accelerated soil erosion and poor infiltration, natural hazards such as droughts and floods (Choudhari et al. 2018).

In earlier times, the studies based on morphometric analysis were executed using traditional methods, which were time-consuming, laborious and were prone to errors and subsequently required information related to physiography, slope, geology, soil data through topographic maps and field surveys (Sreedevi et al. 2013). But due to the recent advancement of remote sensing and GIS (Geographic Information System) techniques has made it very easy and convenient to assess morphometric characteristics of any drainage basin, as it provides recent information with a large spatial synoptic view (Mundetia et al. 2018). The applications of GIS are competent, time-saving and appropriate for three-dimensional planning due to their capability to handle multifaceted problems and big databases for manipulation and retrieval (Kumar et al. 2016).

Studies on morphometric analysis of river basins using remote sensing and GIS technique have been executed by numerous researchers (Nautiyal, 1994; Agarwal, 1998; Nag and Chakraborty, 2003; Chopra et al. 2005; Yadav et al. 2014; Bogale, 2021). Vijith and Satheesth (2006) performed morphometric analysis of two major upland sub-watersheds of the Meenachil river in Kerela. Altaf et al. (2013) performed morphometric analysis to infer hydrological behavior of Lidder watershed, Western Himalaya, India. Madolli et al. (2021) studied the drainage characteristics and their implications for watershed management in Dharma river basin of Karnataka state in India.

The integrated use of remote sensing and GIS techniques can aid in understanding the hydrological behavior of sub-watersheds through morphometric analysis. Keeping in view the above facts, the present study aims at assessing the morphometric characteristics of sub-watersheds inherent in Burhner river watershed situated in Mandla, Balaghat and Dindori districts of Madhya Pradesh, India using remote sensing and GIS technique.

\section{MATERIALS AND METHODS}

\section{Study area}

Burhner river watershed lies between $80^{\circ} 34^{\prime} 40^{\prime \prime} \mathrm{E}$ to $81^{\circ} 23^{\prime} 20^{\prime \prime} \mathrm{E}$ longitudes and $22^{\circ} 49^{\prime} 45^{\prime \prime} \mathrm{N}$ to $22^{\circ} 31^{\prime} 00^{\prime \prime} \mathrm{N}$ latitudes coinciding with Mandla, Balaghat and Dindori districts of Madhya Pradesh. The watershed elevation varies from $393 \mathrm{~m}$ to $954 \mathrm{~m}$ covering a total geographical area of $3959.813 \mathrm{~km}^{2}$. The rainfall in the watershed prominently occurs from the middle of June to the middle of September. The watershed receives rainfall from the southwest monsoon and the normal annual rainfall of the watershed is 1647.8 $\mathrm{mm} /$ year (Pai et al. 2014). The location map of the study area is shown in Fig. 1.

\section{Data source and methodology}

The delineation of watershed boundary and subwatersheds of study area were performed in ArcGIS 9.3® environment by using CARTOSAT DEM (Digital Elevation Model). CARTOSAT DEM of $30 \mathrm{~m}$ spatial resolution was procured from Bhuvan ISRO's 
Geoportal with URL: https://bhuvan-app3.nrsc.gov. in/data/download/index.php. The delineation was performed using snap pour point methodology in case of watershed delineation, whereas the automatic watershed delineation tool of ArcSWAT was considered for sub-watersheds delineation. The sub-watersheds code map of the study area is shown in Fig. 2.

Stream network of the study area was obtained from DEM using the fill, flow direction, flow accumulation tools of the Arc toolbox. A channel initiation threshold value of 30 was used to obtain the stream network of the study area. Strahler (1952; 1964) method of stream ordering was adopted in the present study.

For preparing the base map of the study area, a total number of fourteen toposheets coinciding with the study area were used. Toposheets of Survey of India (SOI) with toposheet number as $64 \mathrm{~B} / 9,64 \mathrm{~B} / 10$, 64B/11, 64B/12, 64B/13, 64B/14, 64B/15, 64B/16, $64 \mathrm{~F} / 2,64 \mathrm{~F} / 3,64 \mathrm{~F} / 4,64 \mathrm{~F} / 6,64 \mathrm{~F} / 7$ and $64 \mathrm{G} / 1$ with a scale of 1:50000 were used. The toposheets were georeferenced in ERDAS IMAGINE® 2011 using Geographic Coordinate System (GCS) as WGS 1984. The georeferenced toposheets were further merged so as to validate the stream order obtained from DEM.

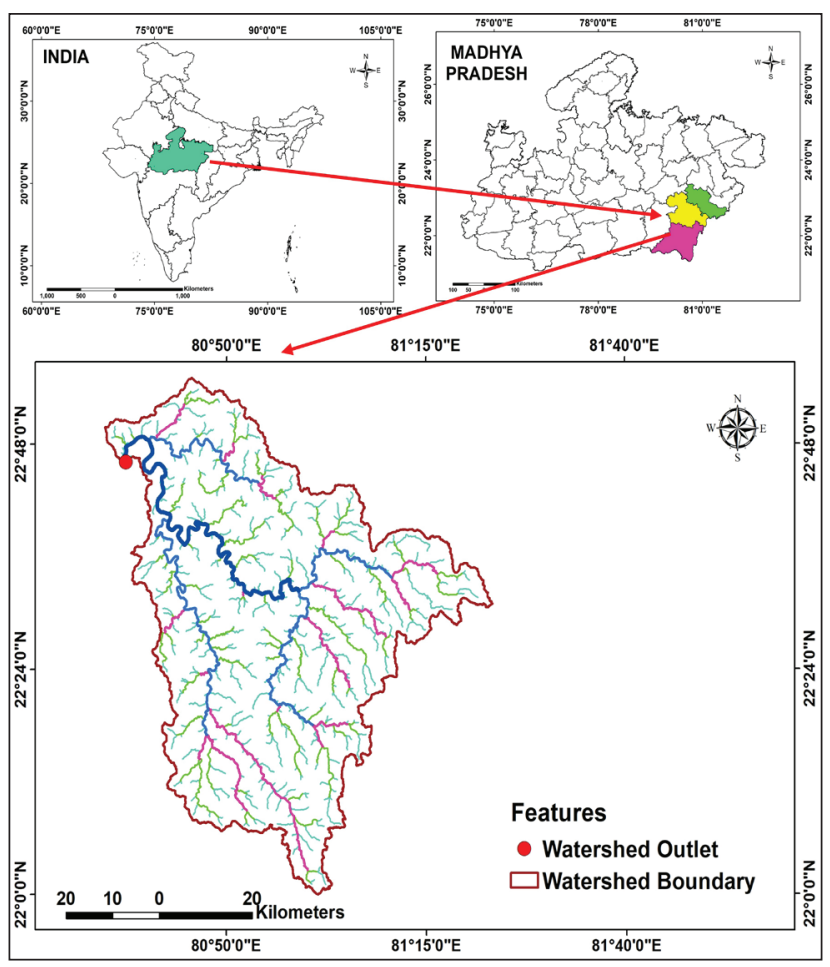

Fig. 1: Location map of the study area

\section{Morphometric analysis}

Morphometric analysis of a drainage basin is considered as the most satisfactory method; this method enables us to find interrelationship among different aspects of a drainage pattern (Biswas et al. 1999), facilitate a comparative evaluation of different drainage basins developed in various geologic and climatic regimes and define certain useful variables of drainage basins in practical terms ( $\mathrm{Nag}$ and Chakraborty, 2003).

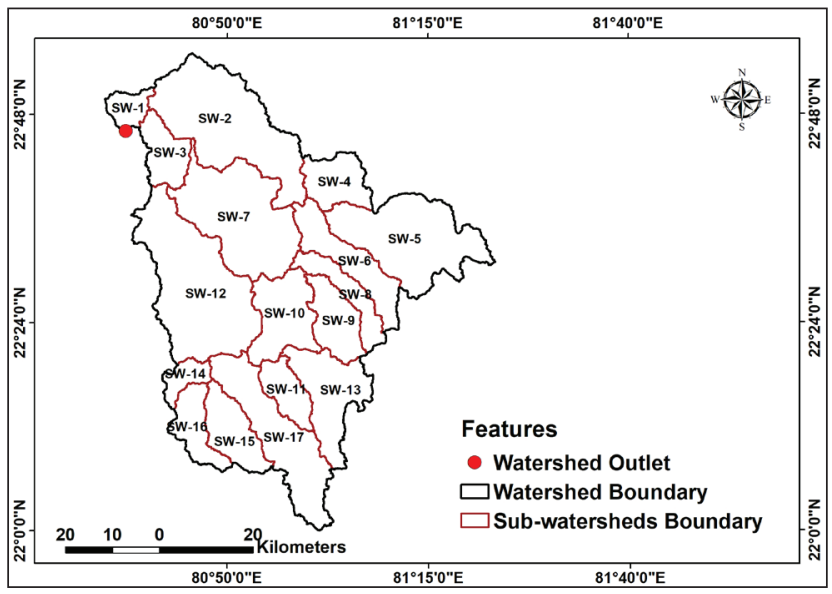

Fig. 2: Sub-watersheds code map of the study area

The preliminary process involved in morphometric analysis is the process of stream ordering $(\mathrm{u})$. Gravelius (1914), Horton (1945) and Strahler (1952; 1964) have elaborated stream order in different ways. As Strahler's method of stream ordering is simple and widely accepted for applications and it is extensively used by geomorphologists for the morphometric analysis of a river basin (Wakode et al. 2013; Hayakawa and Oguchi 2013), the method of stream ordering as proposed by Strahler (1952; 1964) was adopted in the present study.

The basic morphometric parameters such as area (A), perimeter $(\mathrm{P})$ and stream length $\left(\mathrm{L}_{\mathrm{u}}\right)$ of subwatersheds were calculated in GIS environment. The values of maximum watershed relief $\left(\mathrm{H}_{\max }\right)$ and minimum watershed relief $\left(\mathrm{H}_{\text {min }}\right)$ were obtained from depressionless DEM after filling the sinks in the DEM. However, the basin length $\left(\mathrm{L}_{\mathrm{b}}\right)$ and total relief $(\mathrm{H})$ of the sub-watersheds were calculated using the standard formulas as given in Table 1.

Apart from basic morphometric parameters, linear morphometric parameter such as mean bifurcation ratio $\left(R_{b m}\right)$, areal morphometric parameters such as drainage density $\left(D_{d}\right)$, stream frequency $\left(F_{s}\right)$, texture 
ratio $\left(R_{t}\right)$, length of overland flow $\left(L_{o}\right)$, constant of channel maintenance $(\mathrm{C})$, shape morphometric parameters such as form factor $\left(\mathrm{F}_{\mathrm{f}}\right)$, circularity ratio $\left(R_{c}\right)$, elongation ratio $\left(R_{e}\right)$, compactness coefficient $\left(C_{c}\right)$, shape factor $\left(B_{s}\right)$ and relief morphometric parameters such as relief ratio $\left(R_{h}\right)$, relative relief $\left(R_{r}\right)$ and ruggedness number $\left(R_{N}\right)$ were calculated using standard formulas as stated by Gravelius (1914), Horton (1932; 1945), Strahler (1952; 1957; 1964), Schumm (1956), Smith (1950), Miller (1953), Melton (1957), Gregory and Walling (1973), Reddy et al. (2004) and Nooka Ratnam et al. (2005) as given in Table 1.

\section{RESULTS AND DISCUSSION}

\section{Basic morphometric parameters}

The Table 2 shows complete numeric details of the basic morphometric parameters obtained from GIS environment and standard formulas. The watershed with the maximum area was detected for SW-12 (i.e. $564.973 \mathrm{~km}^{2}$ ), whereas it was least for SW-14 (i.e. $56.398 \mathrm{~km}^{2}$ ). In the case of the perimeter, SW-2 indicated the highest value of perimeter (i.e. 181.260 $\mathrm{km})$ and SW-1 indicated the least value of perimeter (i.e. $50.220 \mathrm{~km}$ ). For basin length $\left(\mathrm{L}_{\mathrm{b}}\right)$, the $\mathrm{SW}-12$ indicated the highest values (i.e. $47.983 \mathrm{~km}$ ) and SW-14 indicated the least value (i.e. $12.961 \mathrm{~km}$ ). The high elevation value dominated in SW-5 (i.e. $954 \mathrm{~m}$ ), whereas the least elevation value dominated in SW-1 (i.e. $393 \mathrm{~m}$ ) near the watershed outlet. Among all the sub-watersheds, maximum elevation difference was indicated by SW-2 (i.e. $461 \mathrm{~m}$ ).

\section{Stream order (u)}

Stream order is a type of classification that reflects a pattern of branches that unite to form the trunk stream leaving the catchment (Subramanya 2013). It is a measure of the position of streams in the hierarchy of the tributaries (Horton 1945). Stream order is a form of designation allocated to streams prevailing within the watershed boundaries and is a preliminary process in the morphometric analysis (Rao et al. 2020). The Burhner river watershed showed $8^{\text {th }}$ order stream as a trunk stream. In addition, among the 17 delineated sub-watersheds, six sub-watersheds were of $6^{\text {th }}$ order, eight subwatersheds were of $7^{\text {th }}$ order and 3 sub-watersheds were of $8^{\text {th }}$ order (Table 3 ). The stream network map of the study area is shown in Fig. 3.

\section{Drainage pattern}

Stream order plays a crucial role in designating the nature of the drainage pattern of a watershed (Subramanya, 2013). The analysis of drainage patterns in Burhner river watershed revealed that the watershed comprises of dendritic to subdendritic drainage patterns. The dendritic drainage pattern is characterized by irregular branching in all directions, with the tributaries joining the mainstream at all angles (Zerntiz 1932). The word "dendritic" in the drainage pattern shows a close resemblance to a tree's branching. If the geologic setting is uniformly resistant to erosion, the land surface is gently sloped and surficial deposits are horizontally layered, a dendritic drainage pattern develops (Chow 1965). Such drainage patterns indicate homogenous soil and rock structures (Mishra and Rai 2020).

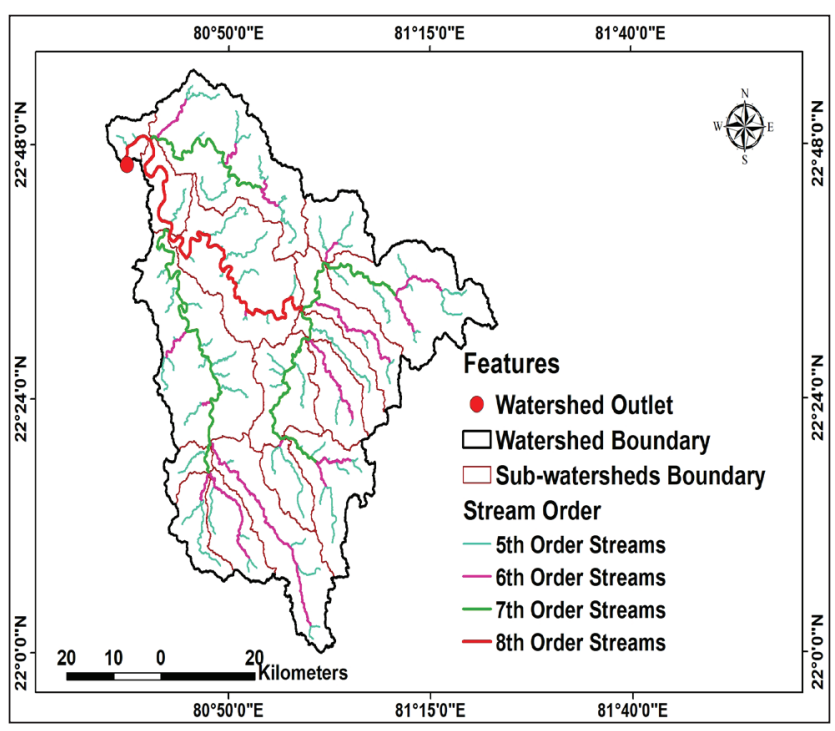

Fig. 3: Stream network map of the study area

\section{Stream number $\left(\mathbf{N}_{\mathrm{u}}\right)$}

Stream number refers to stream segments of different orders in a drainage basin (Horton 1945). The stream number is inversely proportional to the stream order (Meshram and Sharma 2017). The Table 3 shows the stream number of all sub-watersheds. The total number of first order streams in case of all subwatersheds were highest as compared to the higher order streams. SW-12 indicated highest number of first order streams (i.e. $\mathrm{N}_{1}=5314$ ) followed by SW-2 (i.e. $\mathrm{N}_{1}=4628$ ) and SW-7 (i.e. $\mathrm{N}_{1}=4321$ ). 
Table 1: Formulas of different morphometric parameters

\begin{tabular}{|c|c|c|c|c|c|}
\hline S1. No. & $\begin{array}{l}\text { Morphometric } \\
\text { parameters }\end{array}$ & Symbol & Formula & Unit & References \\
\hline \multicolumn{6}{|c|}{ Basic morphometric parameters } \\
\hline 1 & Area & $A$ & GIS environment calculation & $\mathrm{km}^{2}$ & - \\
\hline 2 & Perimeter & $P$ & GIS environment calculation & $\mathrm{km}$ & - \\
\hline 3 & Basin length & $L_{b}$ & $L_{b}=1.312 \times \mathrm{A}^{0.568}$ & $\mathrm{~km}$ & $\begin{array}{l}\text { Schumm (1956); Nooka } \\
\text { Ratnam et al. (2005) }\end{array}$ \\
\hline 4 & $\begin{array}{l}\text { Maximum } \\
\text { watershed relief }\end{array}$ & $H_{\max }$ & $\begin{array}{l}\text { Obtained from depressionless } \\
\text { DEM in GIS environment }\end{array}$ & $\mathrm{m}$ & - \\
\hline 5 & $\begin{array}{l}\text { Minimum watershed } \\
\text { relief }\end{array}$ & $H_{\text {min }}$ & $\begin{array}{l}\text { Obtained from depressionless } \\
\text { DEM in GIS environment }\end{array}$ & $\mathrm{m}$ & - \\
\hline 6 & $\begin{array}{l}\text { Total watershed } \\
\text { relief }\end{array}$ & $H$ & $H=H_{\max }-H_{\min }$ & $\mathrm{m}$ & Schumm (1956) \\
\hline 7 & Stream order & $u$ & Hierarchical rank & Dimensionless & $\begin{array}{l}\text { Strahler (1952); Strahler } \\
\text { (1964) }\end{array}$ \\
\hline 8 & Stream length & $L_{u}$ & $\begin{array}{l}\text { Length of stream of a given order } \\
\text { (u) }\end{array}$ & $\mathrm{km}$ & Horton (1945) \\
\hline \multicolumn{6}{|c|}{ Linear morphometric parameters } \\
\hline \multirow[t]{3}{*}{9} & Bifurcation ratio & $R_{b}$ & $R_{b}=\frac{N_{u}}{N_{u+1}}$ & Dimensionless & $\begin{array}{l}\text { Horton (1945); Schumm } \\
\text { (1956) }\end{array}$ \\
\hline & & & $\begin{array}{l}\text { where } N_{u}=\text { number of streams of } \\
\text { a given order }(u) \text {, }\end{array}$ & & \\
\hline & & & $\begin{array}{l}N_{u+1}=\text { number of streams of next } \\
\text { higher order }(u+1)\end{array}$ & & \\
\hline 10 & $\begin{array}{l}\text { Mean bifurcation } \\
\text { ratio }\end{array}$ & $R_{b m}$ & $\begin{array}{l}R_{b m}=\text { Average of bifurcation } \\
\text { ratios of all orders }\end{array}$ & Dimensionless & Strahler (1957) \\
\hline \multicolumn{6}{|c|}{ Areal morphometric parameters } \\
\hline 11 & Drainage density & $D_{d}$ & $\begin{array}{l}\qquad D_{d}=\frac{\Sigma L_{u}}{A} \\
\text { where } \Sigma L_{u} \text { is the total length of } \\
\text { streams of all orders }(u) \text { within } \\
\text { the drainage basin }\end{array}$ & $\begin{array}{l}\mathrm{km} / \mathrm{km}^{2} \text { or } 1 / \\
\mathrm{km} \text { or } \mathrm{km}^{-1}\end{array}$ & Horton (1932) \\
\hline 12 & Stream frequency & $F_{s}$ & $\begin{array}{l}\qquad F_{s}=\frac{\Sigma N_{u}}{A} \\
\text { where } \Sigma N_{u} \text { is the total number of } \\
\text { streams of all orders }(u) \text { within } \\
\text { the drainage basin }\end{array}$ & $1 / \mathrm{km}^{2}$ or $\mathrm{km}^{-2}$ & Horton (1932) \\
\hline 13 & Texture ratio & $R_{t}$ & $\begin{array}{l}\qquad R_{t}=\frac{N_{1}}{P} \\
\text { where } N_{1}=\text { total number of first } \\
\text { order streams }\end{array}$ & $1 / \mathrm{km}$ or $\mathrm{km}^{-1}$ & $\begin{array}{l}\text { Smith (1950); Reddy } \\
\text { et al. (2004) }\end{array}$ \\
\hline 14 & $\begin{array}{l}\text { Length of overland } \\
\text { flow }\end{array}$ & $L_{o}$ & $L_{o}=\frac{1}{2 D_{d}}$ & $\mathrm{~km}^{2} / \mathrm{km}$ or $\mathrm{km}$ & Horton (1945) \\
\hline 15 & $\begin{array}{l}\text { Constant of channel } \\
\text { maintenance }\end{array}$ & C & $C=\frac{1}{D_{d}}$ & $\mathrm{~km}^{2} / \mathrm{km}$ or $\mathrm{km}$ & Schumm (1956) \\
\hline
\end{tabular}


Shape morphometric parameters

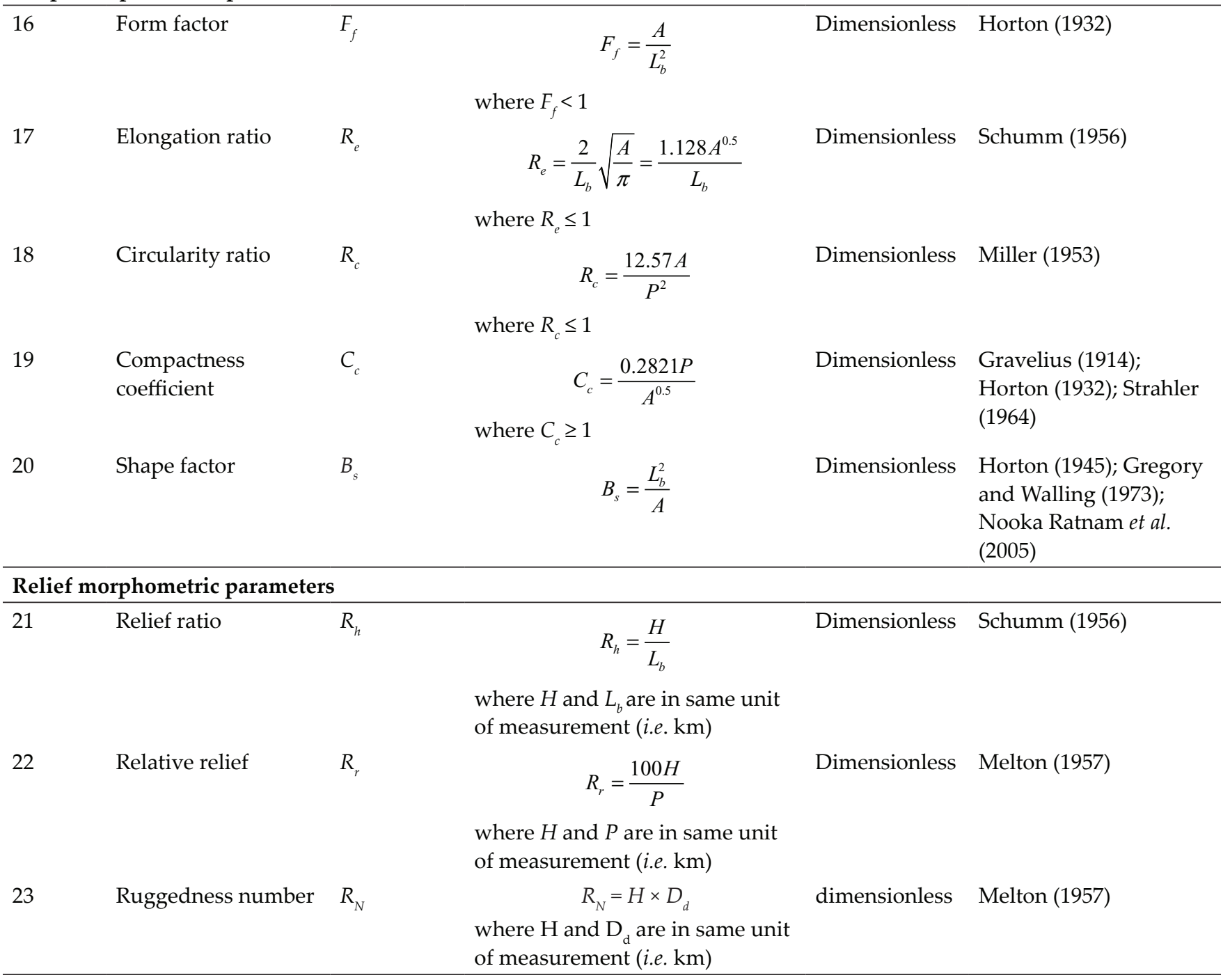

\section{Stream length $\left(\mathrm{L}_{\mathrm{u}}\right)$}

Stream length refers to the length of the stream of a given order $(\mathrm{u})$. The stream length of streams for all orders was determined using GIS environment and is illustrated in Table 4 for all sub-watersheds. It indicates that the total length of first-order streams in all sub-watersheds is highest among the remaining order streams. The drainage pattern of the Burhner river watershed showed absolute conformity with the Horton's law of stream number. In addition to it, the total length of streams gradually decreased with the subsequent order of streams (Mishra and Rai 2020).

\section{Linear morphometric parameters}

\section{Bifurcation ratio $\left(\mathbf{R}_{\mathrm{b}}\right)$}

As stated by Horton (1945), bifurcation ratio is defined as the ratio of number of streams of a given order $\left(\mathrm{N}_{\mathrm{u}}\right)$ to the number of streams of the next higher order $\left(\mathrm{N}_{\mathrm{u}+1}\right)$. It is mathematically denoted by $R_{b}$. The lower bifurcation ratio values are characteristics of the watershed, which has suffered fewer structural disturbances and the drainage pattern has not been distorted by structural disturbances (Nag and Chakraborty 2003).

\section{Mean bifurcation ratio $\left(\mathrm{R}_{\mathrm{bm}}\right)$}

The mean bifurcation ratio $\left(\mathrm{R}_{\mathrm{bm}}\right)$ is defined as the average of bifurcation ratio of all orders (Strahler, 1957). High $R_{b m}$ indicates an early hydrograph peak with a potential of flash flooding during the storm events (Kumar et al. 2000). High values of $R_{b m}$ are the characteristics of structurally more distributed watersheds with a prominent distortion in drainage patterns (Nag 1998). Table 5 shows the mean 
Table 2: Details of basic morphometric parameters of 17 sub-watersheds of Burhner River watershed

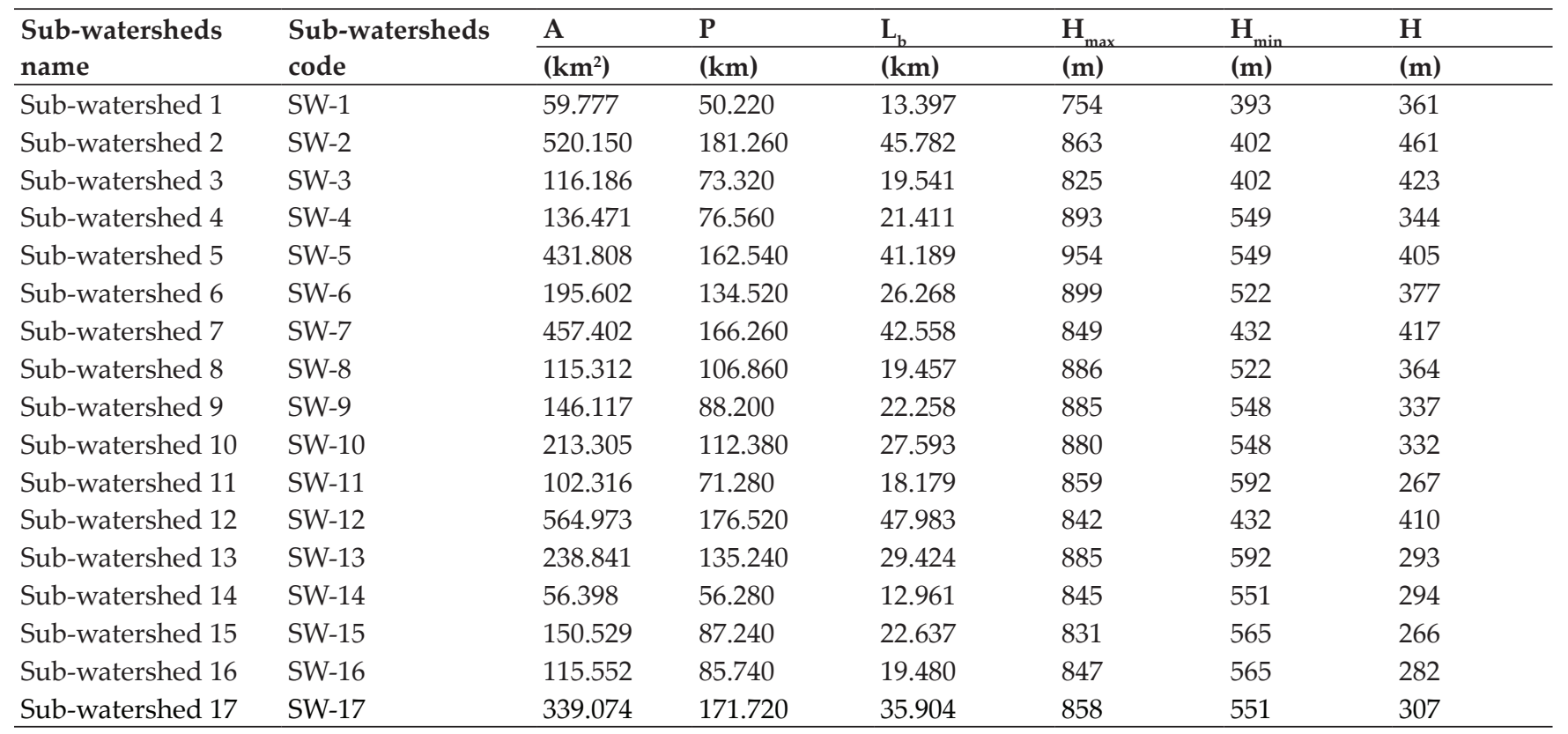

where, $A$-sub-watershed area, $P$ - perimeter of sub-watershed, $L_{b}$ - basin length, $H_{\text {max }}$ - maximum watershed relief in sub-watershed, $H_{\text {min }}$ minimum watershed relief in sub-watershed, $\mathrm{H}$ - total sub-watershed relief.

Table 3: Details of stream number and stream order of 17 sub-watersheds of Burhner river watershed

\begin{tabular}{|c|c|c|c|c|c|c|c|c|c|c|}
\hline \multirow[t]{2}{*}{ Sub-watersheds code } & \multicolumn{8}{|c|}{ Stream numbers $\left(\mathbf{N}_{\mathrm{u}}\right)$} & \multirow{2}{*}{$\begin{array}{l}\text { Total number } \\
\text { of streams of all orders } \\
\sum \mathrm{N}_{\mathrm{u}}\end{array}$} & \multirow[t]{2}{*}{ Stream order } \\
\hline & $\mathbf{N}_{1}$ & $\mathbf{N}_{2}$ & $\mathbf{N}_{3}$ & $\mathbf{N}_{4}$ & $\mathbf{N}_{5}$ & $\mathbf{N}_{6}$ & $\mathbf{N}_{7}$ & $\mathbf{N}_{8}$ & & \\
\hline SW-2 & 4628 & 1029 & 238 & 52 & 11 & 4 & 1 & 0 & 5963 & $7^{\text {th }}$ Order \\
\hline SW-3 & 1072 & 245 & 61 & 11 & 1 & 0 & 1 & 1 & 1392 & $8^{\text {th }}$ Order \\
\hline SW-6 & 1854 & 413 & 96 & 21 & 3 & 2 & 1 & 0 & 2390 & $7^{\text {th }}$ Order \\
\hline SW-7 & 4321 & 926 & 215 & 48 & 11 & 1 & 2 & 1 & 5525 & $8^{\text {th }}$ Order \\
\hline SW-8 & 1157 & 270 & 59 & 9 & 1 & 1 & 1 & 0 & 1498 & $7^{\text {th }}$ Order \\
\hline SW-9 & 1429 & 321 & 78 & 17 & 3 & 1 & 0 & 0 & 1849 & $6^{\text {th }}$ Order \\
\hline SW-13 & 2368 & 554 & 116 & 28 & 8 & 2 & 1 & 0 & 3077 & $7^{\text {th }}$ Order \\
\hline SW-14 & 515 & 116 & 27 & 6 & 1 & 2 & 1 & 0 & 668 & $7^{\text {th }}$ Order \\
\hline SW-15 & 1511 & 346 & 73 & 14 & 4 & 1 & 0 & 0 & 1949 & $6^{\text {th }}$ Order \\
\hline SW-16 & 1070 & 238 & 49 & 9 & 2 & 1 & 0 & 0 & 1369 & $6^{\text {th }}$ Order \\
\hline SW-17 & 3287 & 755 & 162 & 33 & 5 & 1 & 0 & 0 & 4243 & $6^{\text {th }}$ Order \\
\hline
\end{tabular}

bifurcation ratio values of all 17-sub-watersheds of Burhner river watershed. In numeric terms, the mean bifurcation ratio varies between 2 in flat and rolling surface to 4 or 5 in mountainous or highly dissected drainage basins (Horton 1945). According to Strahler (1964), where the $\mathrm{R}_{\mathrm{bm}}$ ranges between 3 and 5, geological structures do not hold a dominant control over the drainage basin. SW-17 indicated the highest value of $R_{b m}$ (i.e. 5.105), specifying early hydrograph peak, less time of concentration and thus designating the region under higher risks of soil erosion induced from a high probability of 
flooding. On the contrary, the minimum value of $\mathrm{R}_{\mathrm{bm}}$ was shown by SW-1 (i.e. 3.277), indicating flat topography and less susceptibility towards soil erosion than SW-17.

\section{Areal morphometric parameters}

\section{Drainage density $\left(D_{d}\right)$}

As stated by Horton (1945), drainage density $\left(D_{d}\right)$ is the average length of streams within the basin per unit area. In mathematical terms, drainage density can be defined as the ratio of the total length of streams of all orders to the area of a basin with $\mathrm{km} /$ $\mathrm{km}^{2}$ or $1 / \mathrm{km}$ as its unit of measurement. $D_{d}$ aids in analyzing the measurement of landscape dissection and run-off potential (Reddy et al. 2004). If $\mathrm{D}_{\mathrm{d}}$ is nearly zero, it specifies a permeable basin with high infiltration rates and high groundwater potential. High $D_{d}$ indicates impermeable rocks with sparse vegetation and a hilly relief region (Horton 1945). High $D_{d}$ is observed in weak and impermeable sub-surface materials and sparse vegetation with mountainous relief (Nag 1998).

In contrast, low and moderate values of $D_{d}$ reveal permeable subsurface materials, good vegetation cover and low relief values as the primary characteristics (Nag and Chakraborty 2003). Higher $D_{d}$ values clearly illustrate less time of concentration, low opportunity time for infiltration suggesting higher risks of soil erosion induced from significant surface runoff. A close observation of obtained numeric values of $D_{d}$ for all sub-watersheds indicated high values. Such higher $D_{d}$ values among all sub-watersheds were due to the predominance of a higher number of first and second order streams, thus increasing the overall length of streams of all orders. Among all the 17 sub-watersheds, SW-16 specified highest values of $\mathrm{D}_{\mathrm{d}}$ (i.e. $4.425 \mathrm{~km} / \mathrm{km}^{2}$ ), indicating higher susceptibility to soil erosion as compared to SW-2 with least values of $\mathrm{D}_{\mathrm{d}}$ (i.e. 4.031 $\mathrm{km} / \mathrm{km}^{2}$ ).

\section{Stream frequency $\left(F_{s}\right)$}

Stream frequency is defined as the ratio of a total number of streams of all orders to the area of the basin. High stream frequencies are indicative of regions with greater surface runoff and steep ground slopes (Horton 1932; 1945). The $\mathrm{F}_{\mathrm{s}}$ value of watersheds is indicative of permeability, infiltration capacity and relief of watersheds (Montgomery and Dietrich, 1989; 1992). High values of $\mathrm{F}_{\mathrm{s}}$ among all sub-watersheds clearly illustrate a high number

Table 4: Details of stream length of 17 sub-watersheds of Burhner river watershed

\begin{tabular}{|c|c|c|c|c|c|c|c|c|c|}
\hline \multirow{2}{*}{$\begin{array}{l}\text { Sub- } \\
\text { watersheds } \\
\text { code }\end{array}$} & \multicolumn{8}{|c|}{ Stream length $\left(\mathrm{L}_{\mathrm{u}}\right)$} & \multirow{2}{*}{$\begin{array}{l}\text { Total stream } \\
\text { length }\end{array}$} \\
\hline & $\mathbf{L}_{1}$ & $\mathbf{L}_{2}$ & $\mathbf{L}_{3}$ & $\mathbf{L}_{4}$ & $\mathbf{L}_{5}$ & $\mathbf{L}_{6}$ & $\mathbf{L}_{7}$ & $\mathrm{~L}_{8}$ & \\
\hline & \multicolumn{9}{|c|}{$(\mathrm{km})$} \\
\hline SW-1 & 129.538 & 58.654 & 32.304 & 17.733 & 5.967 & 0.000 & 0.015 & 8.932 & 253.143 \\
\hline SW-2 & 1114.600 & 503.354 & 236.045 & 106.009 & 67.350 & 28.614 & 40.708 & 0.000 & 2096.680 \\
\hline SW-3 & 254.695 & 121.439 & 59.648 & 15.866 & 9.407 & 0.000 & 0.034 & 26.562 & 487.651 \\
\hline SW-4 & 306.929 & 146.401 & 73.752 & 32.269 & 19.313 & 5.527 & 0.000 & 0.000 & 584.191 \\
\hline SW-5 & 960.427 & 426.409 & 211.634 & 98.841 & 44.051 & 23.753 & 21.372 & 0.000 & 1786.487 \\
\hline SW-6 & 431.336 & 209.090 & 101.174 & 41.920 & 9.546 & 26.359 & 13.600 & 0.000 & 833.025 \\
\hline SW-7 & 1025.022 & 452.307 & 222.327 & 95.920 & 49.156 & 1.279 & 0.030 & 62.492 & 1908.533 \\
\hline SW-8 & 273.767 & 123.104 & 58.097 & 23.111 & 23.020 & 0.016 & 7.051 & 0.000 & 508.166 \\
\hline SW-9 & 336.681 & 154.110 & 74.689 & 39.464 & 7.899 & 22.248 & 0.000 & 0.000 & 635.091 \\
\hline SW-10 & 475.228 & 232.612 & 105.545 & 45.811 & 25.021 & 0.048 & 29.429 & 0.000 & 913.694 \\
\hline SW-11 & 246.301 & 106.876 & 45.759 & 26.563 & 23.640 & 1.619 & 0.000 & 0.000 & 450.758 \\
\hline SW-12 & 1249.208 & 578.697 & 287.928 & 117.753 & 67.382 & 11.446 & 64.058 & 0.000 & 2376.472 \\
\hline SW-13 & 517.179 & 251.097 & 113.198 & 56.897 & 32.722 & 14.783 & 10.943 & 0.000 & 996.819 \\
\hline SW-14 & 119.251 & 63.496 & 24.081 & 9.769 & 9.294 & 0.040 & 6.486 & 0.000 & 232.417 \\
\hline SW-15 & 369.429 & 164.938 & 59.694 & 29.265 & 18.137 & 22.759 & 0.000 & 0.000 & 664.222 \\
\hline SW-16 & 281.208 & 127.362 & 52.829 & 18.596 & 25.129 & 6.195 & 0.000 & 0.000 & 511.319 \\
\hline SW-17 & 779.668 & 345.337 & 173.208 & 85.835 & 17.998 & 47.579 & 0.000 & 0.000 & 1449.625 \\
\hline
\end{tabular}


Table 5: Details of linear and areal morphometric parameters of 17 sub-watersheds of Burhner river watershed

\begin{tabular}{|c|c|c|c|c|c|c|}
\hline \multirow[t]{2}{*}{ Sub-watersheds code } & \multicolumn{2}{|l|}{$\begin{array}{c}\text { Linear morphometric } \\
\text { parameters }\end{array}$} & \multicolumn{3}{|c|}{ Areal morphometric parameters } & \multirow[b]{2}{*}{$\mathrm{C}$} \\
\hline & $\mathbf{R}_{\mathrm{bm}}$ & $\mathrm{D}_{\mathrm{d}}$ & $\mathbf{F}_{\mathrm{s}}$ & $\mathbf{R}_{t}$ & $\mathbf{L}_{\mathrm{o}}$ & \\
\hline SW-1 & 3.277 & 4.235 & 12.246 & 11.031 & 0.118 & 0.236 \\
\hline SW-4 & 4.215 & 4.281 & 11.783 & 16.301 & 0.117 & 0.234 \\
\hline SW-5 & 4.207 & 4.137 & 12.357 & 25.360 & 0.121 & 0.242 \\
\hline SW-6 & 3.977 & 4.259 & 12.219 & 13.782 & 0.117 & 0.235 \\
\hline SW-7 & 4.474 & 4.173 & 12.079 & 25.989 & 0.120 & 0.240 \\
\hline SW-11 & 4.333 & 4.406 & 12.891 & 14.015 & 0.113 & 0.227 \\
\hline SW-12 & 4.251 & 4.206 & 12.036 & 30.104 & 0.119 & 0.238 \\
\hline SW-13 & 3.782 & 4.174 & 12.883 & 17.510 & 0.120 & 0.240 \\
\hline SW-14 & 3.623 & 4.121 & 11.844 & 9.151 & 0.121 & 0.243 \\
\hline SW-15 & 4.364 & 4.413 & 12.948 & 17.320 & 0.113 & 0.227 \\
\hline SW-16 & 4.259 & 4.425 & 11.847 & 12.480 & 0.113 & 0.226 \\
\hline SW-17 & 5.105 & 4.275 & 12.513 & 19.142 & 0.117 & 0.234 \\
\hline
\end{tabular}

where $R_{b m}$ - mean bifurcation ratio, $D_{d}$ - drainage density, $F_{s}$ - stream frequency, $R_{t}$ - texture ratio, $L_{o}$ - length of overland flow, $C$ - constant of channel maintenance.

Table 6: Details of shape morphometric parameters of 17 sub-watersheds of Burhner river watershed

Sub-watersheds code

Shape morphometric parameters

\begin{tabular}{|c|c|c|c|c|c|}
\hline & $F_{f}$ & $\mathbf{R}_{\mathrm{c}}$ & 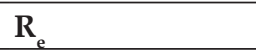 & 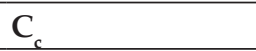 & $\mathbf{B}_{\mathrm{s}}$ \\
\hline & (Dimensionless) & (Dimensionless) & (Dimensionless) & (Dimensionless) & (Dimensionless) \\
\hline SW-1 & 0.333 & 0.298 & 0.651 & 1.832 & 3.002 \\
\hline SW-3 & 0.304 & 0.272 & 0.622 & 1.919 & 3.286 \\
\hline SW-4 & 0.298 & 0.293 & 0.616 & 1.849 & 3.359 \\
\hline SW-7 & 0.253 & 0.208 & 0.567 & 2.193 & 3.960 \\
\hline SW-8 & 0.305 & 0.127 & 0.623 & 2.807 & 3.283 \\
\hline SW-9 & 0.295 & 0.236 & 0.613 & 2.058 & 3.391 \\
\hline SW-10 & 0.280 & 0.212 & 0.597 & 2.171 & 3.570 \\
\hline SW-15 & 0.294 & 0.249 & 0.612 & 2.006 & 3.404 \\
\hline SW-16 & 0.305 & 0.198 & 0.623 & 2.250 & 3.284 \\
\hline SW-17 & 0.263 & 0.145 & 0.579 & 2.631 & 3.802 \\
\hline
\end{tabular}

where $F_{f}$ - form factor, $R_{c}$ - circularity ratio, $R_{e}$ - elongation ratio, $C_{c}$ - compactness coefficient, $B_{s}$ - shape factor. 
of streams in the sub-watersheds indicative of early hydrograph peak, less time of concentration designating greater risks of soil erosion resulting from a high-intensity rainfall event.

In the present study, SW-2 showed the least $\mathrm{F}_{\mathrm{s}}$ (as $11.464 \mathrm{~km}^{-2}$ ) whereas SW-8 showed the highest $\mathrm{F}_{\mathrm{s}}$ (as $12.991 \mathrm{~km}^{-2}$ ), which represent the highest susceptibility of soil erosion in SW-8 and least in SW-2 as compared to all other sub-watersheds.

\section{Texture ratio $\left(\mathbf{R}_{\mathrm{t}}\right)$}

Texture ratio is defined as the ratio of a total number of first-order streams to the perimeter of the watershed (Smith 1950; Nooka Ratnam et al. 2005). Texture ratio depends on the underlying geology, infiltration capacity of bedrock and relief aspects of the basin (Reddy et al. 2004). Higher number of first-order streams per unit perimeter of watershed clearly indicates higher susceptibility towards soil erosion due to less soil resistance and high reliefs (Altin and Altin 2011). The highest value of $R_{t}$ was detected in SW-12 (i.e. $\mathrm{R}_{\mathrm{t}}=30.104 \mathrm{~km}^{-1}$ ), illustrating greater risk from soil erosion, whereas it was lowest in the case of SW-14 ((i.e. $\left.R_{t}=9.151 \mathrm{~km}^{-1}\right)$, indicating a comparatively lesser risk from soil erosion with reference to $\mathrm{SW}-12$.

\section{Length of overland flow $\left(\mathrm{L}_{\mathrm{o}}\right)$}

The term "length of overland flow" expressed as $\mathrm{L}_{\mathrm{o}}$ is used to describe the length of the flow of water over the ground before it becomes concentrated in definite stream channels (Horton 1945). In a watershed, the overland flow and channel flow are the two common types of flow prominent due to rainfall. The overland flow is distinguished by a thin layer of water flowing over a wide surface, which occurs at the upper reaches of the flow before the flow terminates into a channel (Suresh 2012). Length of overland flow is defined as half of the reciprocal of drainage density (Horton 1945; Schumm 1956). As the name suggests, the unit of measurement of $\mathrm{L}_{\mathrm{o}}$ is in $\mathrm{km}$.

Lower values of $\mathrm{L}_{\mathrm{o}}$ for all sub-watersheds as shown in Table 5, clearly illustrate that channel flow dominates in the watershed due to the large watershed area and high values of stream frequencies. From Table 5, it is observed that SW-8, SW-11, SW-15 and SW-16 indicate lower values of $L_{0}$ (i.e. $\mathrm{L}_{\mathrm{o}}=0.113 \mathrm{~km}$ ) and $\mathrm{SW}-2$ indicates the highest value of $\mathrm{L}_{\mathrm{o}}$ among all the 17 sub-watersheds (i.e. $\mathrm{L}_{\mathrm{o}}$ $=0.124 \mathrm{~km}$ ).

\section{Constant of channel maintenance (C)}

Schumm (1956) has defined constant of channel maintenance as the reciprocal of drainage density $\left(D_{d}\right)$. Its unit of measurement is $\mathrm{km}^{2} / \mathrm{km}$. Half of the constant of channel maintenance equals the length of overland flow (Chow, 1965). Constant of channel maintenance signifies how much area is required to maintain a unit length of channel (Shulits 1968). The value of $C$ depends upon not only on the rock type and permeability, climatic regime, vegetation cover and relief but also on the duration of erosion and climatic history (Nag and Chakraborty 2003). Lower values of $C$ interpret weak or low resistance soils, sparse vegetation and mountainous terrain (Shulits 1968). Table 5 shows the values of $C$ for all 17 sub-watersheds of Burhner river watershed. It is visible from Table 5 that SW-16 indicates the lowest value of $C$ (i.e. $\left.C=0.226 \mathrm{~km}^{2} / \mathrm{km}\right)$, specifying a greater level of risk from soil erosion, whereas SW-2 posses' highest value of C (i.e. C $=0.248 \mathrm{~km}^{2}$ / $\mathrm{km}$ ) representing a comparatively lower risk from soil erosion.

\section{Shape morphometric parameters}

\section{Form factor $\left(F_{f}\right)$}

Horton (1932) defined the form factor as the ratio of basin area (A) to the square of the basin length $\left(\mathrm{L}_{\mathrm{b}}\right)$. In case of perfectly squared basins, the value of $F_{f}$ should always be less than 0.7854 (Nautiyal 1994). The smaller the value of $F_{f}$ the more elongated is the basin (Nag and Chakraborty 2003). The basins with high $\mathrm{F}_{\mathrm{f}}$ have a high rate of peak flows for a shorter duration, whereas elongated basins with low $\mathrm{F}_{\mathrm{f}}$ have a lower peak of flows for a longer duration (Nautiyal 1994). Among all the 17 sub-watersheds of Burhner river watershed (Table 6), SW-12 illustrated the least value of $F_{f}\left(\right.$ i.e. $\left.F_{f}=0.245\right)$ and on the contrary, SW-14 indicated the highest value of $\mathrm{F}_{\mathrm{f}}$ (i.e. $\mathrm{F}_{\mathrm{f}}=0.336$ ), which clearly states that $\mathrm{SW}-12$ is at the highest level of risk from soil erosion.

\section{Circularity ratio $\left(\mathbf{R}_{\mathrm{c}}\right)$}

Miller (1953) stated circularity ratio as the ratio between the area of the basin and the area of the 
Table 7: Details of relief morphometric parameters of 17 sub-watersheds of Burhner river watershed

\begin{tabular}{|c|c|c|c|}
\hline Sub-w & & Relief morphom & \\
\hline & $\mathbf{R}_{\mathrm{h}}$ & $\mathbf{R}_{r}$ & $\mathbf{R}_{\mathrm{N}}$ \\
\hline & (Dimensionless) & (Dimensionless) & (Dimensionless) \\
\hline SW-1 & 0.027 & 0.719 & 1.529 \\
\hline SW-2 & 0.010 & 0.254 & 1.858 \\
\hline SW-3 & 0.022 & 0.577 & 1.775 \\
\hline SW-5 & 0.010 & 0.249 & 1.676 \\
\hline SW-6 & 0.014 & 0.280 & 1.606 \\
\hline SW-7 & 0.010 & 0.251 & 1.740 \\
\hline SW-8 & 0.019 & 0.341 & 1.604 \\
\hline SW-9 & 0.015 & 0.382 & 1.465 \\
\hline SW-14 & 0.023 & 0.522 & 1.212 \\
\hline SW-15 & 0.012 & 0.305 & 1.174 \\
\hline SW-16 & 0.014 & 0.329 & 1.248 \\
\hline SW-17 & 0.009 & 0.179 & 1.313 \\
\hline
\end{tabular}

where $R_{h}$ - relief ratio, $R_{r}$ - relative relief and $R_{N}$ - ruggedness number.

circle having same perimeter to that of the basin. The circularity ratio makes a comparative evaluation between the area of the drainage basin (A) to the area of a circle $\left(A_{c}\right)$ having the same circumference (Miller, 1953). In general, watersheds with lower values of $R_{c}$ (i.e. $R_{c}=0.4$ ) are more elongated in shape and are likely controlled by geologic settings and structure (Chow, 1965). More round basins have $R_{c}$ ranging from 0.6 to 0.7 (Fryirs and Brierley, 2013). The value of $R_{c}$ ranged from 0.127 to 0.298 for all the sub-watersheds with the highest values in the case of SW-1 (i.e. $\mathrm{R}_{\mathrm{c}}=0.298$ ) and lowest in the case of SW-8 (i.e. 0.127). Such values evidently illustrate the higher level of susceptibility associated with soil erosion in SW-8.

\section{Elongation ratio $\left(R_{\mathrm{e}}\right)$}

Elongation ratio is the ratio of the diameter of a circle having the same area (as that of the basin) and the maximum length of the basin (Schumm 1956). The value of elongation ratio ranges from 0.4 to 1.0 or $\leq 1$ over a wide range of geologic and climatic conditions. Value of $R_{e}$ closer to 1 is indicative of very low relief, while $R_{e}$ value ranging between 0.4 to 0.8 shows regions of very high reliefs and steep ground slopes (Malik et al. 2019). The least value of $\mathrm{R}_{\mathrm{e}}$ was indicated by SW-12 (i.e. $\left.\mathrm{R}_{\mathrm{e}}=0.559\right)$ while it was highest for $\mathrm{SW}-14$ (i.e. $\mathrm{R}_{\mathrm{e}}=0.654$ ) which stated that SW-12 is highly susceptible to soil erosion and SW-14 is at lowest risk from soil erosion.

\section{Compactness coefficient $\left(\mathrm{C}_{\mathrm{c}}\right)$}

Compactness coefficient $\left(\mathrm{C}_{\mathrm{c}}\right)$ is defined as the ratio of the perimeter of the watershed to the perimeter of an equivalent circular area of a watershed (Horton 1945; Strahler 1964). The compactness coefficient is also known as Gravelius Index and its value is always $\geq 1$. A circular basin yields the shortest time of concentration before peak flow occurs in the basin with $C_{C}=1$, for $C_{C}=1.28$, watersheds are square-shaped and for $C_{C}$ value greater than 3.0 watersheds are varying in their shape (Zavoianu 1985; Altaf et al. 2013). Large deviation of $C_{C}$ values from unity is indicative of the large time of concentration, whereas closeness of $C_{C}$ to unity directs circular behavior of the basin (Mokarram and Sathyamoorthy 2015). The value of $C_{C}$ in 17 sub-watersheds (Table 6) ranges from 1.832 to 2.807 with highest value for $\mathrm{SW}-8$ (i.e. $\mathrm{C}_{\mathrm{C}}=2.807$ ) and lowest value for $\mathrm{SW}-1$ (i.e. $\mathrm{C}_{\mathrm{C}}=1.832$ ) indicating greater levels of susceptibility towards soil erosion in SW-1 among all other sub-watersheds and least susceptibility in case of SW-8. 


\section{Shape factor $\left(B_{s}\right)$}

Shape factor is defined as the ratio of square of the a basin length $\left(\mathrm{L}_{\mathrm{b}}\right)$ to the area of basin (A) (Nooka Ratnam et al. 2005). High values of shape factors reveals high basin length which specifies high time of concentration and longer basin lag time whereas lower value of $B_{s}$ shows low time of concentration and shorter basin lag time. In the present study, the value of $\mathrm{B}_{\mathrm{s}}$ ranged between 2.979 to 4.075 (Table 6) illustrating highest value for $\mathrm{SW}-12$ (i.e. $\mathrm{B}_{\mathrm{s}}=4.075$ ) whereas least value for $\mathrm{SW}-14$ (i.e. $\mathrm{B}_{\mathrm{s}}=2.979$ ) thus designating SW-14 at greater risk of soil erosion and SW-12 at least risk.

\section{Relief morphometric parameters}

\section{Relief ratio $\left(R_{h}\right)$}

Relief ratio is defined as the ratio between total relief of a basin (elevation difference of lowest and highest points of a basin) and the longest dimension of the basin $\left(\mathrm{L}_{b}\right)$ parallel to the main drainage line (Schumm 1956). Field studies conducted by Hadley and Schumm (1961) reveal that residuals or abnormally high points on the divide should be ignored when obtaining total relief values of the basin. On a quantitative basis, it is the measurement of the overall steepness of the drainage basin (Altaf et al. 2013). In addition to it, $R_{h}$ is an indicator of the intensity of erosion processes operating on the basin slopes (Dodov and Foufoula-Georgiou 2005). $R_{h}$ holds an inverse relationship with drainage basin area typically. A close inspection of $R_{h}$ values in Table 7 illustrates that $S W-1$ holds highest $R_{h}$ value (i.e. $\left.\mathrm{R}_{\mathrm{h}}=0.027\right)$, indicating potential threat from soil erosion in SW-1 whereas SW-12 and SW-17 hold the lowest value (i.e. $R_{h}=0.009$ ), thus representing its status as least susceptible to soil erosion.

\section{Relative relief $\left(R_{\mathrm{r}}\right)$}

Relative relief is defined as the ratio of the basin relief to the basin's perimeter. (Melton 1957). The best advantage of relative relief $\left(R_{r}\right)$ over relief ratio $\left(R_{h}\right)$ is that for determining the value of $R_{r}$ both the values of basin area (A) and perimeter of the basin $(\mathrm{P})$ are readily available as such values are used for computation of other morphometric parameters. From Table 7, it is clear that SW-1 holds the highest value of $R_{r}$ (i.e. $R_{r}=0.719$ ). In contrast, it is least for SW-17 (i.e. $\mathrm{R}_{\mathrm{r}}=0.179$ ), thus indicating that SW-1 is highly susceptible to soil erosion among all the sub-watersheds, whereas SW-17 is least affected by soil erosion.

\section{Ruggedness number $\left(R_{N}\right)$}

Ruggedness number is the product of maximum basin relief to the drainage density in the same unit of measurement (Melton 1957). Higher basin relief and high drainage density are indicative of a steep slope which directly raises the values of $R_{N}$ (Hema et al. 2021). From Table 7, it is clear that SW-15 indicates the lowest value of $R_{N}$ (i.e. $R_{N}=$ 1.174) and SW-2 indicates the highest value of $R_{N}$ (i.e. $\mathrm{R}_{\mathrm{N}}=1.858$ ), which clearly states that $\mathrm{SW}-2$ is highly susceptible to soil erosion as compared to all other sub-watersheds whereas SW-15 is at least risk among all the sub-watersheds.

\section{CONCLUSION}

Remote sensing and GIS have proved to be effective in morphometric studies of watersheds. The present study attempts to understand the hydrological behaviors of sub-watersheds inherent in Burhner river watershed. Among the 17 delineated subwatersheds of Burhner river watershed, three subwatersheds were of $8^{\text {th }}$ order, eight sub-watersheds were of $7^{\text {th }}$ order and six sub-watersheds were of $6^{\text {th }}$ order revealing dendritic to sub-dendritic drainage patterns. Basic morphometric parameters were calculated using GIS environment and standard formulas at the initial level. Based on the obtained values of basic morphometric parameters, linear, areal, shape and relief morphometric parameters were assessed using the standard formulas. Among all the sub-watersheds, the number of first order streams and the overall total length of first order streams were highest. High mean bifurcation ratio $\left(R_{b m}\right)$ values indicated geomorphological control over the sub-watersheds. High values of areal parameters such as drainage density $\left(D_{d}\right)$, stream frequency $\left(\mathrm{F}_{\mathrm{s}}\right)$, texture ratio $\left(\mathrm{R}_{\mathrm{t}}\right)$ indicated channel flow as the dominating flow in the sub-watersheds with lower numeric values of length of overland flow $\left(\mathrm{L}_{\mathrm{o}}\right)$ supporting it. Beside it, the lower value of the constant channel maintenance $(C)$ indicated weak or low resistance soils. Smaller form factor values $\left(F_{f}\right)$ stated the elongated shape of the subwatersheds. Lower values of circularity ratio $\left(R_{c}\right)$ also supported that shape of sub-watersheds is 
elongated with elongation ratio $\left(\mathrm{R}_{\mathrm{e}}\right)$, indicating mountainous relief in the sub-watersheds. Higher values of compactness coefficient $\left(\mathrm{C}_{\mathrm{c}}\right)$ and shape factor $\left(\mathrm{B}_{\mathrm{s}}\right)$ illustrated a large time of concentration in the sub-watersheds. Besides the linear, areal and shape morphometric parameters, higher values of relief morphometric parameters such as relief ratio $\left(R_{h}\right)$, relative relief $\left(R_{r}\right)$ and ruggedness number $\left(R_{N}\right)$ specified the risks associated with high relief and large $\mathrm{D}_{\mathrm{d}}$ of sub-watersheds.

\section{REFERENCES}

Agarwal, C.S. 1998. Study of drainage pattern through aerial data in Naugarh area of Varanasi district, UP. J. Indian Soc. Remote Sens., 26(4): 169-175.

Ahmed, R., Sajjad, H. and Husain, I. 2018. Morphometric parameters-based prioritization of sub-watersheds using fuzzy analytical hierarchy process: A case study of lower Barpani Watershed, India. Nat. Resour. Res., 27(1): 67-75.

Altaf, F., Meraj, G. and Romshoo, S.A. 2013. Morphometric analysis to infer hydrological behaviour of Lidder watershed, Western Himalaya, India. Geogr. J., https:// dx.doi.org/10.1155/2013/178021

Altın, T.B. and Altın, B.N. 2011. Drainage morphometry and its influence on landforms in volcanic terrain, Central Anatolia, Turkey. Procedia-Soc Behav. Sci., 19: 732-740.

Biswas, S., Sudhakar, S. and Desai, V.R. 1999. Prioritisation of subwatersheds based on morphometric analysis of drainage basin: A remote sensing and GIS approach. J. Indian Soc. Remote Sens., 27(3): 155-166.

Bogale, A. 2021. Morphometric analysis of a drainage basin using geographical information system in Gilgel Abay watershed, Lake Tana Basin, upper Blue Nile Basin, Ethiopia. Appl. Water Sci., 11(7): 1-7

Chopra, R., Dhiman, R.D. and Sharma, P.K. 2005. Morphometric analysis of sub-watersheds in Gurdaspur district, Punjab using remote sensing and GIS techniques. J. Indian Soc. Remote Sens., 33(4): 531-539.

Choudhari, P.P., Nigam, G.K., Singh, S.K. and Thakur, S. 2018. Morphometric based prioritization of watershed for groundwater potential of Mula river basin, Maharashtra, India. Geol. Ecol. Landsc., 2(4): 256-267.

Chow, V.T. 1965. Handbook of Applied Hydrology. Int. Assoc. Sci. Hydrol. Bulletin, 10(1).

Clarke, J.I. 1996. Morphometry from maps. Essays in geomorphology. Elsevier Publ., Co., New York, pp 235-274.

Dodov and E. Foufoula-Georgiou. 2005. Fluvial processes and streamflow variability: interplay in the scale-frequency continuum and implications for scaling, Water Resour. Res., 41(5): 1-18.

Fryirs, K.A. and Brierley, G.J. 2013. Geomorphic analysis of river systems: an approach to reading the landscape. John Wiley \& Sons.
Gajbhiye, S. and Sharma, S.K. 2016. Application of principal component analysis of grouping of morphometric parameters and prioritization of watershed. Springer Nature Singapore Pvt. Ltd. 2018 V.P. Singh et al. (eds.), Hydrologic Modeling, Water Science and Technology Library, 81: 447- 458 .

Gajbhiye, S., Sharma, S.K., Tignath, S. and Mishra, S.K. 2015a. Development of geomorphological erosion index for Shakker watershed. J. Geol. Soc. India, 86(3): 361-370.

Gajbhiye, S., Singh, S.K., Sharma, S.K., Siddiqui, A.R. and Singh, P.K. 2015b. Assessing the effects of different land use on water quality using multi temporal Landsat data. Resource management, Development Strategies : A Geographical Perspective, pp. 337-348.

Gravelius, H. 1914. Grundriss der gesamten Gewasserkunder. Flusskunde, 1, Berlin and Leipzig, viii-179.

Gregory, K.J. and Walling, D.E. 1973. Drainage basin form and processes - a geomorphological approach. Edward Arnold, London, U.K.

Hadley, R.F. and Schumm, S.A.1961. Hydrology of the upper Cheyenne River basin. US Geological Survey Water Supply Paper, 1531, 186-198.

Hayakawa, Y.S. and Oguchi, T. 2013. Spatial correspondence of knickzones and stream confluences along bedrock rivers in Japan: implications for hydraulic formation of knickzones. Geografiska Annaler: Series A, Phys. Geogr., 96(1): 9-19.

Hema, H.C., Vittala, S.S. and Govindaiah, S. 2021. Quantitative morphometric infer in the hard rock Terrain based on SRTM-DEM and GIS-Chintamani Watershed, Chikkaballapur District, Karnataka, India. Sustainable Water Resour. Manage., 7(4): 1-12.

Horton, R.E. 1932. Drainage-basin characteristics. Eos, Trans. Am. Geophys. Union, 13(1): 350-361.

Horton, R.E. 1945. Erosional development of streams and their drainage basins; Hydrophysical approach to quantitative morphology. Geol. Soc. Am. Bull., 56(3): 275-370.

Kumar, R., Kumar, A., Ram, D. and Bhat, O.A. 2016. Development of cost effective technology for treatment of torrents in Shivalik hills, India. Indian J. Soil Conserv., 44(1): 25-29.

Kumar, R., Lohani, A.K., Kumar, S., Chatterjee, C. and Nema, R.K. 2000. GIS based Morphometric Analysis of Ajay river basin upto Sarathh gauging site of South Bihar, J. Appl. Hydrol., 14(4): 45-54.

Madolli, U.J., Gudagur, J.T. and Madolli, M.J. 2021. Study of Drainage Characteristics and its Implications for Watershed Management-A Case Study of the Dharma River Basin, Karnataka State, India. Int. J. Ecol. Environ. Sci., 47(2): 135-144.

Malik, A., Kumar, A. and Kandpal, H. 2019. Morphometric analysis and prioritization of sub-watersheds in a hilly watershed using weighted sum approach. Arabian J. Geosci., 12(4): 118.

Mangan, P., Haq, M.A. and Baral, P. 2019. Morphometric analysis of watershed using remote sensing and GIS-a 
case study of Nanganji River Basin in Tamil Nadu, India. Arabian J. Geosci., 12(6): 1-14.

Melton, M.A. 1957. An analysis of the relations among elements of climate, surface properties and geomorphology. Columbia University New York. https://doi.org/10.7916/ d8-0rmg-j112

Meshram, S.G. and Sharma, S.K. 2017. Prioritization of watershed through morphometric parameters: a PCAbased approach. Appl. Water Sci., 7(3): 1505-1519.

Meshram, S.G., Sharma, S.K. and Tignath, S. 2017. Application of remote sensing and geographical information system for generation of runoff curve number. Appl. Water Sci., 7(4): 1773-1779.

Miller, V.C. 1953. A Quantitative Geomorphic Study of Drainage Basin Characteristics in The Clinch Mountain Area Virginia and Tennessee. Columbia University New York.

Mishra, A.K. and Rai, S.C. 2020. Geo-hydrological inferences through morphometric aspects of the Himalayan glacialfed river: a case study of the Madhyamaheshwar River basin. Arabian J. Geosci., 13(13): 1-18.

Mokarram, M. and Sathyamoorthy, D. 2015. Morphometric analysis of hydrological behavior of North Fars watershed, Iran. Eur. J. Geogr., 6(4): 88-106.

Montgomery, D.R. and Dietrich, W.E. 1989. Source areas, drainage density and channel initiation. Water Resour. Res., 25(8): 1907-1918.

Montgomery, D.R. and Dietrich, W.E. 1992. Channel initiation and the problem of landscape scale. 255(5046): 826-830.

Mundetia, N., Sharma, D. and Dubey, S.K. 2018. Morphometric assessment and sub-watershed prioritization of Khari River basin in semi-arid region of Rajasthan, India. Arabian J. Geosci., 11(18): 1-18.

Nag, S.K. 1998. Morphometric analysis using remote sensing techniques in the Chaka sub-basin, Purulia district, West Bengal. J. Indian Soc. Remote Sens., 26(1): 69-76.

Nag, S.K. and Chakraborty, S. 2003. Influence of rock types and structures in the development of drainage network in hard rock area. J. Indian Soc. Remote Sens., 31(1): 25-35.

Nautiyal, M.D. 1994. Morphometric analysis of a drainage basin using aerial photographs: a case study of Khairkuli Basin, District Dehradun, UP. I. Indian Soc. Remote Sens., 22(4): 251-261.

Nooka Ratnam, K., Srivastava, Y.K., Rao, V.V., Amminedu, E. and Murthy K.S.R. 2005. Check dam positioning by prioritization of micro-watersheds using SYI model and morphometric analysis - Remote sensing and GIS perspective. J. Indian Soc. Remote Sens., 33(1): 25-38.

Pai, D.S., Rajeevan, M., Sreejith, O.P., Mukhopadhyay, B. and Satbha, N.S. 2014. Development of a new high spatial resolution $(0.25 \times 0.25)$ long period $(1901-2010)$ daily gridded rainfall data set over India and its comparison with existing data sets over the region. Mausam, 65(1): 1-18.

Patil, R.J., Sharma, S.K., Tignath, S. and Sharma, A.P.M
2017. Use of remote sensing, GIS and $\mathrm{C}^{++}$for soil erosion assessment in Shakker river basin, India. Hydrol. Sci. J., 62(2): 217-231.

Prabhakar, A.K., Singh, K.K., Lohani, A.K. and Chandniha, S.K. 2019. Study of Champua watershed for management of resources by using morphometric analysis and satellite imagery. Appl. Water Sci., 9(5): 1-16.

Puno, G.R. and Puno, R.C.C. (2019). Watershed conservation prioritization using geomorphometric and land use-land cover parameters. Global J. Environ. Sci. Manage., 5(3): 279-294.

Rao, J.H., Patle, D. and Dubey, S. 2020. Implementation of Morphometric Analysis in Prioritizing Sub-Watersheds: A Remote Sensing and GIS Aspect. Indian J. Pure Appl. Biosci., 8(4): 318-329.

Reddy, G.P.O., Maji, A.K. and Gajbhiye, K.S. 2004. Drainage morphometry and its influence on landform characteristics in a basaltic terrain, Central India-a remote sensing and GIS approach. Int. J. Appl. Earth Obs. Geoinf., 6(1): 1-16.

Romshoo, S.A., Bhat, S.A. and Rashid, I. 2012. Geoinformatics for assessing the morphometric control on hydrological response at watershed scale in the Upper Indus Basin. J. Earth Syst. Sci., 121(3): 659-686.

Schumm, S.A. 1956. Evolution of drainage systems and slopes in Badlands at Perth Amboy, New Jersey. Geol. Soc. Am. Bull., 67(5): 597-646.

Sharma, S.K., Gajbhiye, S., Tignath, S. and Patil, R.J. 2016. Hypsometric analysis for assessing erosion status of watershed using geographical information system. (C) Springer Nature Singapore Pvt. Ltd. 2018, V.P. Singh et al. (eds.), Hydrologic Modeling, Water Science and Technology Library 81: 263-276. https://dx.doi. org/10.1007/978-981-10-5801-1_19

Sharma, S.K., Pathak, R. and Suraiya, S. 2012. Prioritization of sub-watersheds based on morphometric analysis using remote sensing and GIS technique. J.N.K.V.V. Res. J., 46(3): 407-413.

Sharma, S.K., Seth, N.K., Tignath, S. and Pandey R.P. 2011. Use of Geographical Information System in hypsometric analysis of watershed. J. Indian Water Resour. Soc., 31(34): 28-32.

Sharma, S.K., Tignath, S. and Mishra, S.K. 2008. Morphometric analysis of Drainage basin using GIS approach. J.N.K.V.V. Res. J., 42(1): 91-95.

Sharma, S.K., Yadav, A. and Gajbhiye, S. 2014. Remote sensing and GIS approach for prioritization of watershed. LAMBERT Academic Publishing.

Shulits, S. 1968. Quantitative formulation of stream and watershed morphology. Bull. Int. Assoc. Sci. Hydrol., 3: 201-207.

Smith, K.G. 1950. Standards for grading texture of erosional topography. Am. J. Sci., 248(9): 655-668.

Sreedevi, P.D., Sreekanth, P.D., Khan, H.H. and Ahmed, S. 2013. Drainage morphometry and its influence on hydrology in an semi-arid region: using SRTM data and GIS. Environ. Earth Sci., 70(2): 839-848. 
Strahler, A.N. 1952. Hypsometric (area-altitude) analysis of erosional topography. Geol. Soc. Am. Bull., 63(11): 11171142.

Strahler, A.N. 1957. Quantitative analysis of watershed geomorphology. Eos, Trans. Am. Geophys. Union, 38(6): 913-920.

Strahler, A.N. 1964. Part II. Quantitative geomorphology of drainage basins and channel networks. Handbook of Applied Hydrology: McGraw-Hill, New York, pp. 4-39.

Subramanya, K. 2013. Engineering hydrology, $4^{\text {th }}$ Edition. Tata McGraw-Hill Education.

Suresh, R. 2012. Soil and water conservation engineering. Standard Publishers Distributors.

Vijith, H. and Satheesh, R. 2006. GIS based morphometric analysis of two major upland sub-watersheds of Meenachil river in Kerala. J. Indian Soc. Remote Sens., 34(2): 181-185.
Wakode, H.B., Dutta, D., Desai, V.R., Baier, K. and Azzam, R. 2013. Morphometric analysis of the upper catchment of Kosi River using GIS techniques. Arabian J. Geosci., 6(2): 395-408.

Yadav, S.K., Singh, S.K., Gupta, M. and Srivastava, P.K. 2014. Morphometric analysis of Upper Tons basin from Northern Foreland of Peninsular India using CARTOSAT satellite and GIS. Geocarto Int., 29(8): 895-914.

Zavoianu, I. 1985. Morphometry of drainage basins (Developments in Water Science). Elsevier, Amsterdam, ISBN: 0-444-99587-0. URL: https://www.elsevier. com/books/morphometry-of-drainage-basins/ zavoianu/978-0-444-99587-2

Zernitz, E.R. 1932. Drainage patterns and their significance. J. Geol., 40(6): 498-521. 
